\title{
The effect of mass transfer resistance on the kinetics of catalytic hydrodesulfurization of thiophene over $\mathrm{Pt} / \mathrm{Al}_{2} \mathrm{O}_{3}$
}

\author{
تأثئي مقاومة انتقال المادة على حركية تفاعل هدرجة الثيوفين لازالة الكبريت بوجود العامل

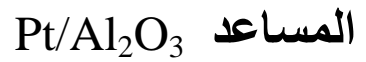

Dr. Saad Hanash Ammar, Chem. Eng. Dept., Al-Nahrain University

\section{ABSTRACT}

In kinetic study of reactions carried out in the presence of heterogeneous catalyst, it is very important to study the effects of mass transfer rate firstly which can be effective in adding to chemical kinetic. The present work investigates the catalytic hydrodesulfurization (HDS) of thiophene over Pt/ $\mathrm{Al}_{2} \mathrm{O}_{3}$, to determine the effect of interface mass transfer resistance. The experimental work was performed in a HDS continuous flow fixed bed catalytic reactor unit consisted of a carbon steel tube $(2.54 \mathrm{~cm}$ diameter, and $60 \mathrm{~cm}$ length), located in the laboratories of chemical engineering department, Baghdad University. The objective of the work was to investigate effect of mass transfer limitations (internal diffusion and external diffusion) in catalytic reaction of thiophene HDS. It was verified that mass transfer resistances has a small effect on the reaction rate.

الخلاصة

عند در اسة حركية التفاعلات التي تجري بوجود الترود

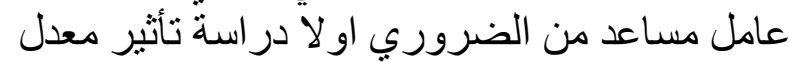

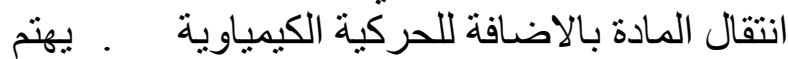
البحث الحالي بدر اسة تفاعل هدرجة الثيوفين لاز الة الة
الكبريت بوجود العامل المساعد وهو البلاتين

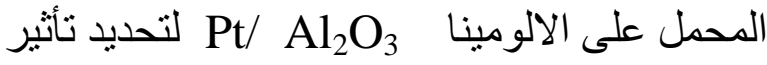
مقاومة الانتتار في السطح البيني ومقاومة الانتشار

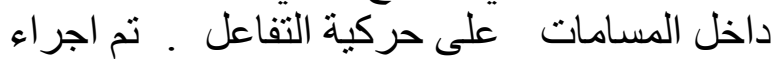
التجارب العملية لتفلعل الهدرجة في وحدة المفاعل

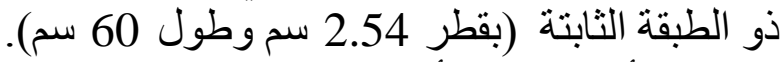
لقد وجد بأنه لا يوجد تأثثير كبير لمحددات انتقال

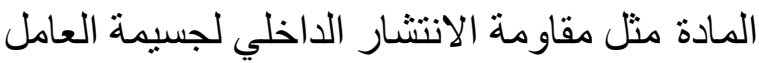
المساعد (داخل المسامات ) ) ومقاومة الانيمار الانتشار الخارجي للجسيمة (الانتشار الغشائي) على حركية الأنية

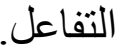

\section{INTRODUCTIO}

Hydrodesulfurization (HDS) is the industrial process in which sulfur is removed from organosulfur compounds found in petroleum feedstocks, in recent years, HDS has gained importance due to more stringent legislations for vehicular emissions and fuel quality and an increasing need to process lowquality oils, which contain larger amounts of sulfur compounds ${ }^{[1]}$.Thiophenic components are known to be the most refractory organic sulfur-containing components present in petroleum fractions. Most studies on HDS kinetics were performed using model sulfur compounds such as thiophene, benzothiophene and dibenzothi- 
ophene. Rigorous kinetics for the HDS of thiophene has already been derived $[2,3]$

The kinetics of thiophene hydrodesulfurization has been widely studied. Most of these studies did not determine the influences of the mass transfer resistance in the presence of Platinum supported on alumina (Pt/ $\mathrm{Al}_{2} \mathrm{O}_{3}$ ) catalyst. Recent work studied the effect of mass transfer resistance foe gas-oil hydrodesulfurization over Cobalt-Molybdenum supported on alumina ${ }^{[4]}$.

Mass transfer limitation can divided in two distinct phenomena, the first mass transfer resistance is pore diffusional limitation, which is defined as the resistance of catalyst pores against reactants entrance and products exit. Another mass transfer limitation is film diffusional limitation, which is defined as the resistance of the gas film around the catalyst, against passing the reactants and products ${ }^{[5,6]}$.

In this study, the effects of pore (internal) diffusion and film (external) diffusion were investigated on the kinetics of catalytic hydrodesulfurization of thiophene using $\mathrm{Pt} / \mathrm{Al}_{2} \mathrm{O}_{3}$ as catalyst.

\section{EXPERIMENTAL AND RESULTS}

Thiophene $\mathrm{C}_{4} \mathrm{H}_{4} \mathrm{~S}$ with $99.9 \%$ purity supplied from Fluka AG, Chem. Company was used as a raw material for catalytic hydrodesulfurization process. The properties of thiophene are tabulated in Table (1).

Table (1): Thiophene properties

\begin{tabular}{|c|c|}
\hline Molecular weight & 84 \\
\hline Boiling point $/{ }^{\circ} \mathrm{C}$ & 84.1 \\
\hline Density $\left(\mathrm{g} / \mathrm{cm}^{3}\right)$ at $16{ }^{\circ} \mathrm{C}$ & 1.071 \\
\hline Flash point $/{ }^{\circ} \mathrm{C}$ & -1 \\
\hline & \\
\hline
\end{tabular}

Platinum supported on alumina $\left(\mathrm{Pt} / \mathrm{Al}_{2} \mathrm{O}_{3}\right)$ supplied from The Middle Refineries Company, Baghdad was used as hydrodesulfurization catalyst. The physical and chemical properties of the catalyst are shown in Table (2). The desired amount of catalyst was placed in the middle zone of the reactor between two beds of glass ball. Presulfiding treatment of the catalyst was performed by $10 \mathrm{H}_{2}$ / Thiophene volume ratio at $400{ }^{\circ} \mathrm{C}$ for $1 \mathrm{hr}$. 
Table (2): Catalyst properties

\begin{tabular}{|c|c|}
\hline Dimensions & $\mathrm{D}=1 \mathrm{~mm}, \mathrm{~L}=2-5 \mathrm{~mm}$ \\
\hline Surface area $\left(\mathrm{m}^{2} / \mathrm{gm}\right)$ & 295 \\
\hline Pore volume $(\mathrm{cc} / \mathrm{gm})$ & 0.58 \\
\hline Density $\left(\mathrm{g} / \mathrm{cm}^{3}\right)$ & 0.56 \\
\hline
\end{tabular}

Hydrodesulfurization of thiophene over $\mathrm{Pt} / \mathrm{Al}_{2} \mathrm{O}_{3}$ was carried out in a conventional fixed-bed flow reactor unit as shown in Fig. (1). The operating conditions are tabulated in Table (3).

Table (3): The experimental conditions

\begin{tabular}{|c|c|}
\hline Parameter & Condition \\
\hline Temperature $\left({ }^{\circ} \mathrm{C}\right)$ & 350 \\
\hline Pressure $(\mathrm{atm})$. & Atmospheric \\
\hline Catalyst weight $(\mathrm{gm})$ & 10 and 20 \\
\hline $\begin{array}{c}\text { Liquid Hourly Space Velocity, LHSV }\left(\mathrm{hr}^{-}\right. \\
\left.{ }^{-}\right)\end{array}$ & $1,2,3,4,5$, and 6 \\
\hline $\mathrm{H}_{2} /$ Thiophene ratio $(\mathrm{Vol} \%)$ & 10 \\
\hline
\end{tabular}




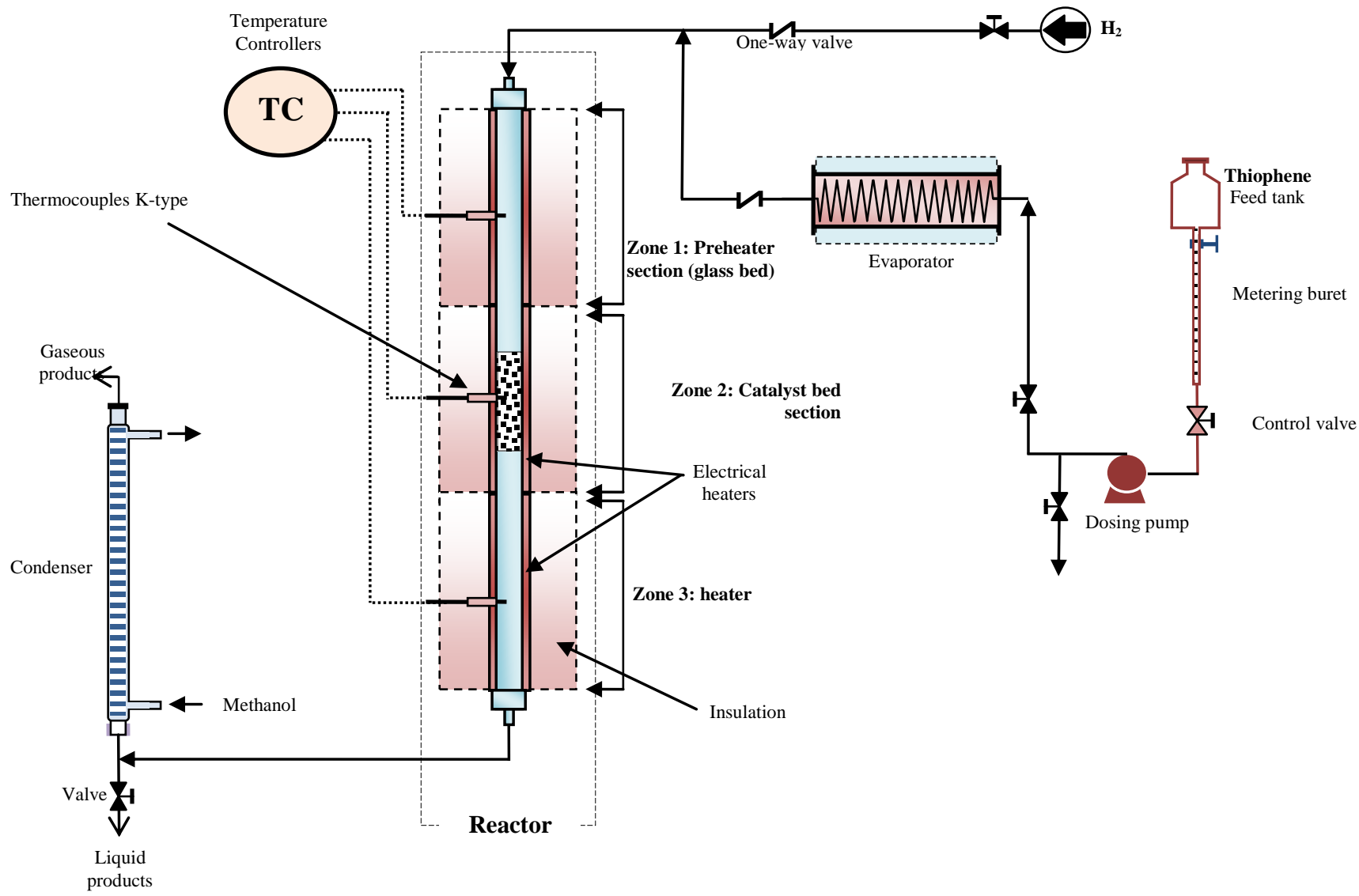

Figure (1): Schematic flow diagram of the experimental unit

Liquid thiophene feed was pumped by a dosing pump at the prespecified rate to the evaporator. The evaporator consists of coil of copper tubes $(10 \mathrm{~m}$ long with $5 \mathrm{~mm}$ i.d.). The heat was supplied by using $3 \mathrm{KW}$ electrical heater to heat and evaporate the feed to the desired temperature controlled by voltage regulator. Thiophene vapor feed was mixed with hydrogen and then passed through the upper preheating section and in downflow through the reactor, distributed uniformly and reacted on the catalyst. The vapor of product passed through the condenser (using methanol as cooling medium) and the condensates were collected. The reactor was heated and con- 
trolled automatically by three steelJacket heaters. The fixed bed catalytic reactor consisted of a carbon steel tube with $2.54 \mathrm{~cm}$ diameter, and $60 \mathrm{~cm}$ length.

In the beginning the reaction was preceded continuously for about 20 min to reach a steady state conversion and reaction temperature. During this time the liquid product was collected by the waste-product receiver. After that time liquid samples were taken.

Some gas product samples were analyzed by the gas chromatography analysis (Packard 438A located in IbnSina State Company), thiophene was not detected in the gas product stream; all unreacted thiophene was condensed and present in liquid product stream only. Therefore, the percentage conversion of HDS reaction can be calculated by the volume of the feed and unreacted thiophene $(\mathrm{ml})$ respectively within about $10 \mathrm{~min}$.

To investigate the pore diffusion limitation, Two catalyst dimensions were used firstly the commercial catalyst with real dimensions $(D=1.5 \mathrm{~mm}$,
$\mathrm{L}=5 \mathrm{~mm}$ ) has been used. In this set the conversion of reaction was measuredwith various feed flow and different feed to catalyst ratio (LHSV from 1 to $\left.6 \mathrm{hr}^{-1}\right)$. Then catalyst was broken to small particles, and previous tests were repeated by using catalyst particle size of range $(0.1-0.25 \mathrm{~mm})$, in the same reactor. In these two sets of experiments, the conversion of HDS reaction was measured with the same amounts of feed flow, LHSV ratio $\left(1-6 \mathrm{hr}^{-1}\right)$ and catalyst weight (20 gm).

The results of these experiments have been summarized in Fig. (2). With comparison of two curves, it is observed that when reducing catalysts particle size to very small size, the conversion of reaction has not changed significantly. So it can be found that mass transfer resistant spring from pore diffusion has not effect on the reaction kinetic because the reaction rate was not affected when the behavior of particle size changed ${ }^{[5]}$. 


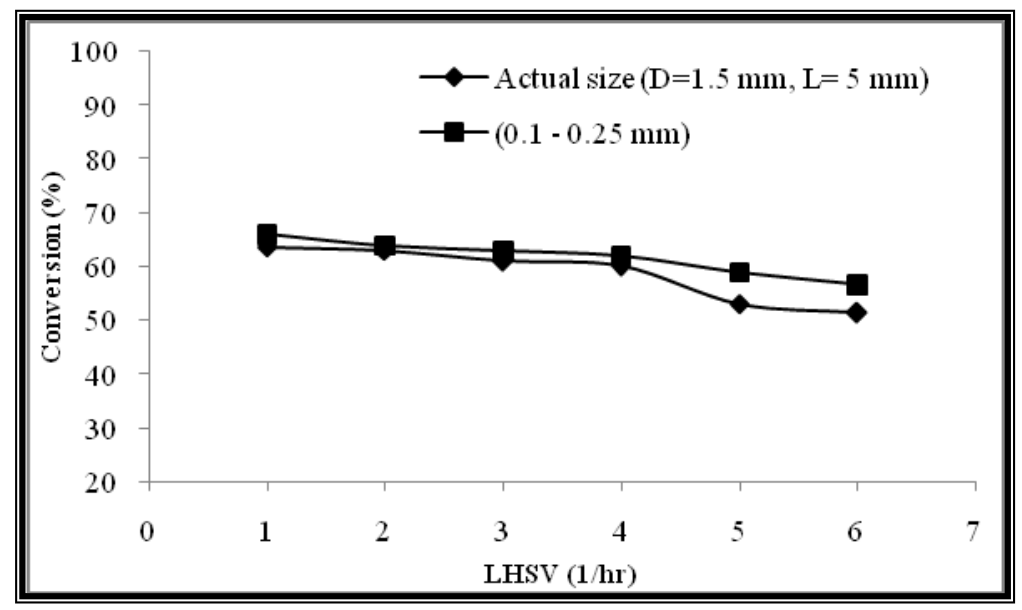

Figure (2): The effect of pore diffusional limitation

To determine the effect of film diffusional limitation, some tests were performed using two weights of catalyst sample 20 and $10 \mathrm{gm}$ of the real dimensions $(\mathrm{D}=1.5 \mathrm{~mm}, \mathrm{~L}=5 \mathrm{~mm})$. In these tests, flow of feed passing trough catalyst bed was changed to vary the amount of fluid velocity or in the other word to change the LHSV, and conversion of HDS reaction in any set points was measured

The results of these two sets of tests have been illustrated in Fig. (3). It is clear that even the velocity of fluid increase to four times, the conversion of HDS reaction has not vary significantly. Therefore it is verified that mass transfer resistant spring from film diffusion has small role in the reaction.

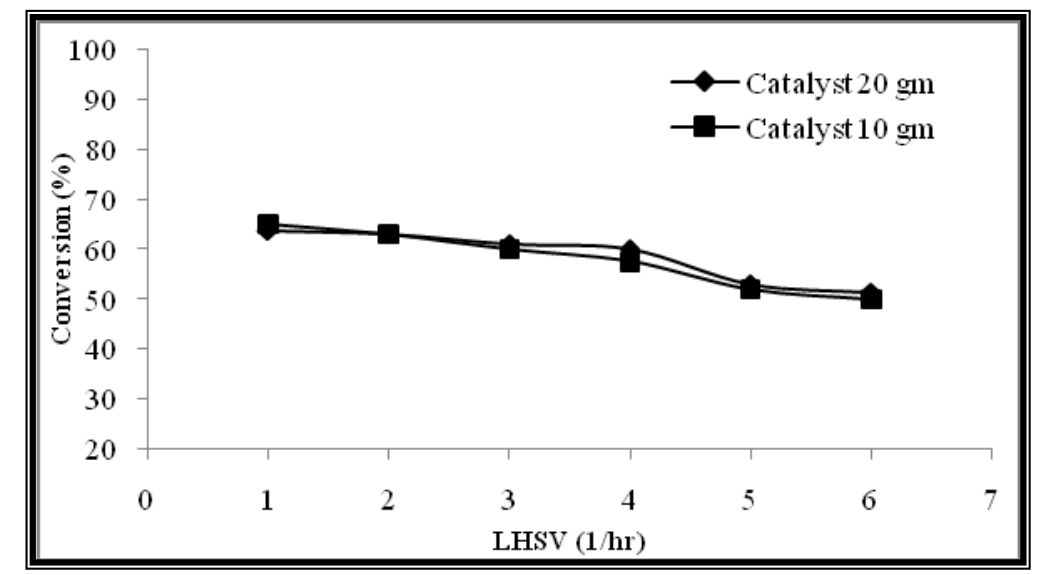

Figure (3): The effect of film diffusional limitation 


\section{CONCLUSION}

In this study the kinetics of thiophene hydrodesulfurization over Pt/ $\mathrm{Al}_{2} \mathrm{O}_{3}$ catalyst was investigated. For this purpose the effect of interface mass transfer resistance was evaluated. Pore diffusional limitation was studied by comparisons of reaction conversion obtained from actual size catalyst particles and $(0.1-0.25) \mathrm{mm}$ catalyst particles. By comparison of conversions rate it was found that the reaction kinetics does not affected largely by pore diffusion. Furthermore, film diffusional limitation was investigated by comparison of conversions from some fluid velocity passing through the reactor. It is proved that film diffusion has small effect on the reaction rate. 


\section{References}

1. Clausen, B. S. and Massoth, F. E., Catal.- Sci. Tech., 11, (1996), p1-310.

2. Van Parijs, I.A., and G.F. Froment. "Kinetics of Hydrodesulfurization on a $\mathrm{CoMo} / \mathrm{Al}_{2} \mathrm{O}_{3}$ Catalyst", Ind. Eng. Chem. Prod. Res. Dev. Vol., 25, 431-436, (1986).

3. Chakraborty P. and Kar A. K., "Kinetics of Hydrogenolysis of Thiophene in Naphtha", Ind. Eng. Chem. Process Des. Dev., Vol. 17, No. 3, (1978).

4. Ghanbari K., Mohammadi M. and Tajerian M., Petroleum \& Coal 48 (2), 33 36, (2006).

5. Levenspiel Octave, "Chemical Reaction Engineering", $3^{\text {ed }}$ ed., John Wiley \& Sons, Inc., New York, (1999).

6. Smith J. M., "Chemical Engineering Kinetics", $3^{\text {ed }}$ ed., McGrawHILL, London, (1981). 


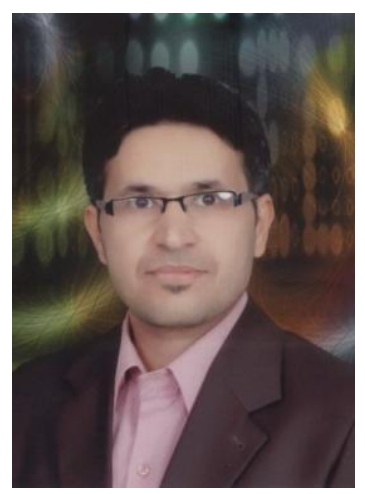

1- Name: Dr. Saad Hanash Ammar

2- Post: Lecturer

3- Date of Birth: 1977

4- Place of work: Chem. Eng. Dept., Al-Nahrain University

\section{5- Academic Qualification:}

- B. Sc., Chem. Eng., Baghdad University 2001

- M.Sc., Chem. Eng., Baghdad University 2004 